\title{
Diet and ecomorphological relationships of an endemic, species-poor fish assemblage in a stream in the Iguaçu National Park
}

\author{
Mayara Pereira Neves ${ }^{1}$, Rosilene Luciana Delariva² and Luciano Lazzarini Wolff ${ }^{3}$
}

This study investigated the morphological and dietary relationships of the fish assemblage in a stream with an endemic fauna and low species richness. The ichthyofauna was sampled quarterly from September 2011 to July 2012, through the electrofishing technique. The stomach contents of 419 individuals belonging to seven species were analyzed by the volumetric method, and the ecomorphological traits of 30 specimens of each species were estimated. The main food items consumed were detritus, aquatic and terrestrial insects, and other aquatic invertebrates. We observed low levels of trophic niche breadth and diet overlap between most species. The PCA scores indicated the occurrence of three ecomorphotypes. PCA axis 1 segregated at one extreme, species with dorsoventrally depressed bodies, longer caudal peduncles, and welldeveloped swimming fins; and at the other extreme, species with compressed bodies and peduncles, and relatively larger eyes and anal fins. PCA axis 2 segregated species with elongated bodies and ventrally oblique mouths. The partial Mantel test revealed a significant correlation between diet and morphology, indicating independence from the phylogeny. The patterns observed suggest that the low richness did not result in a broadening of the species' trophic niches, or in the absence of some of the main ecomorphotypes expected.

Este estudo teve como objetivos investigar as relações morfológicas e alimentares de uma assembleia de peixes com fauna endêmica e de baixa riqueza de espécies. Os peixes foram amostrados trimestralmente entre setembro de 2011 a julho de 2012, através da técnica da pesca elétrica. Foram obtidas as medidas morfométricas que possibilitaram os cálculos dos índices ecomorfológicos e analisados os conteúdos estomacais de 419 indivíduos, pertencentes a sete espécies, através do método volumétrico. Os principais itens alimentares consumidos pela assembleia de peixes foram detrito, insetos aquáticos e terrestres e outros invertebrados aquáticos. Observou-se baixos valores de amplitude de nicho trófico e de sobreposição alimentar entre a maioria das espécies. Os escores da PCA, indicaram a ocorrência de três ecomorfotipos. O eixo CP1 segregou em um extremo espécies com corpo deprimido dorso-ventralmente, pedúnculo caudal longo e as nadadeiras desenvolvidas, enquanto no outro extremo, espécies com corpos e pedúnculos comprimidos, área dos olhos e das nadadeiras anais relativamente maiores. Por outro lado, o eixo CP2 segregou espécies com corpos mais alongados, bocas ventralmente oblíquas. Através do Teste de Mantel verificou-se relação significativa entre a dieta e a morfologia. Assim, os principais padrões tróficos e ecomorfológicos verificados sugerem que a baixa riqueza, não repercutiu no alargamento do nicho trófico das espécies ou na inexistência de algum dos principais grupos ecomorfológicos.

Keywords: Feeding ecology, Iguaçu River basin, Morphotypes, Niche overlap, Stream fishes.

\section{Introduction}

Iguaçu National Park (INP) is known worldwide for the Iguaçu Falls, and represents, in Brazil, one of the largest remaining continuous areas of Atlantic Forest (Tabarelli et al., 2005). Upstream of the falls, the drainage network of the INP is composed of several streams and rivers which flow directly into the main channel of the Iguaçu River. The fish fauna in these systems and all of the Iguaçu River above the falls is endemic, with about $80 \%$ of its species found only in this basin (Garavello et al., 1997; Zawadzki et al., 1999; Baumgartner et al. (2012). This pattern is explained by its geographical isolation from the rest of the fish fauna of the Paraná River basin (Garavello et al., 1997). Assemblages of fish in streams of the Iguaçu River basin contain between six and 10 species (Abilhoa et al., 2008), and the basin as a whole contains about 130 species (Baumgartner et al., 2012). This diversity is low compared to other streams or even to other tributaries of similar order in other stretches of the Paraná River basin (Langeani et al., 2007; Delariva \& Silva, 2013).

${ }^{1}$ Programa de Pós-Graduação em Conservação e Manejo de Recursos Naturais, Rua Universitária 2069, Jardim Universitário, 85819-110 Cascavel, PR, Brazil. mayara-nevesbio@hotmail.com

${ }^{2}$ Universidade Estadual do Oeste do Paraná, Centro de Ciências Biológicas e da Saúde, Programa de Pós-Graduação em Conservação e Manejo de Recursos Naturais, Rua Universitária 2069, Jardim Universitário, 85819-110 Cascavel, PR, Brazil. rosilene.delariva@ unioeste.br

${ }^{3}$ Universidade Estadual do Oeste do Paraná, Centro de Ciências Biológicas e da Saúde, Rua Universitária 2069, Caixa postal 711, 85819-110 Cascavel, PR, Brazil. luciano.wolff@unioeste.br 
These particularities call attention to this fish assemblage, especially outside the area of the INP, where the intensification of hydropower, agricultural and industrial activities has posed serious risks of extinction for their species (Nogueira et al., 2010; Daga et al., 2012). However, singular fish communities such as those in the Iguaçu basin, especially those from streams that are still relatively well preserved, provide a good model to test hypotheses and identify patterns of trophic and ecomorphological structure.

Regarding the trophic structure, it is expected that in fish communities of highly diverse sites, the partition of food resources is a major species-segregation mechanism, resulting in greater specialization or greater overlap in resource use (Ross, 1986; Herder \& Freyhof, 2006). Little is known about how these mechanisms operate in assemblages of tropical fishes with low species richness (Montana et al., 2014; Leduc et al., 2015). It is expected that this condition would lead to the coexistence of species with broad food spectra and low feeding-niche overlap. Moreover, in streams where the structural characteristics of the channel and surroundings are preserved, there is greater availability of food from different sources (autochthonous and allochthonous) (Carvalho \& Uieda, 2010; Cruz et al., 2013). In view of the morphological potential of each species to exploit these food sources, this greater availability may lead to unique or poorly understood patterns of trophic structure.

Determination of the ecomorphological patterns, that is, association the morphology with the ecology of the species, is the first step to test the ecomorphological hypothesis (Casatti \& Castro, 2006). If such associations gain phylogenetic support, i.e., if phylogenetically unrelated species exhibit convergence and related species exhibit morphological divergences, the hypothesis gains considerable power of inference (Wainwright \& Reilly, 1994). Several studies have shown consistent relationships between morphology and feeding habits (Pouilly et al., 2003; Oliveira et al., 2010; Pagotto et al., 2011; Mise et al., 2013), demonstrating different predictive models of community structure (Casatti \& Castro, 2006; Oliveira et al., 2010).

In this context, it is especially interesting to expand the theoretical framework of ecomorphology, through studies of distinct areas with high endemism and low species richness, the typical situation in the Iguaçu River basin (Baumgartner et al., 2012). Thus, in this study, we tested the hypothesis that the low fish richness found in a stream in INP, leads to the absence of certain ecomophological groups, well as the coexistence of species with broad food spectra and low feeding-niche overlap. In this sense, the objectives of this study were to (i) describe the feeding habits of the fish fauna of a stream in Iguaçu National Park; (ii) determine the patterns of niche breadth and trophic overlap; (iii) identify ecomorphological patterns of the fish assemblage; (iv) test the relationships between morphology and diet, controlling the influence of phylogeny.

\section{Material and Methods}

Study area. Gonçalves Dias River, a tributary to the Iguaçu River, is an important water body that delimits the Iguaçu National Park (Baumgartner et al., 2012). Its headwaters are located around the city of Santa Tereza do Oeste, in a forest reserve, Cajati Farm. The river is approximately $106 \mathrm{~km}$ long, and with a stretch of $100 \mathrm{~km}$ comprising the eastern border of the INP.

Sampling area was in the Jumelo stream, a first-order stream that flows into the Gonçalves Dias River, west

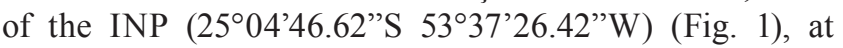
an altitude of $605 \mathrm{~m}$ a.s.l., on the left bank of the stream borders the park. The right bank has a strip of riparian vegetation 5 to $10 \mathrm{~m}$ wide, and its surroundings consist of small farms with pastures and domestic animals.

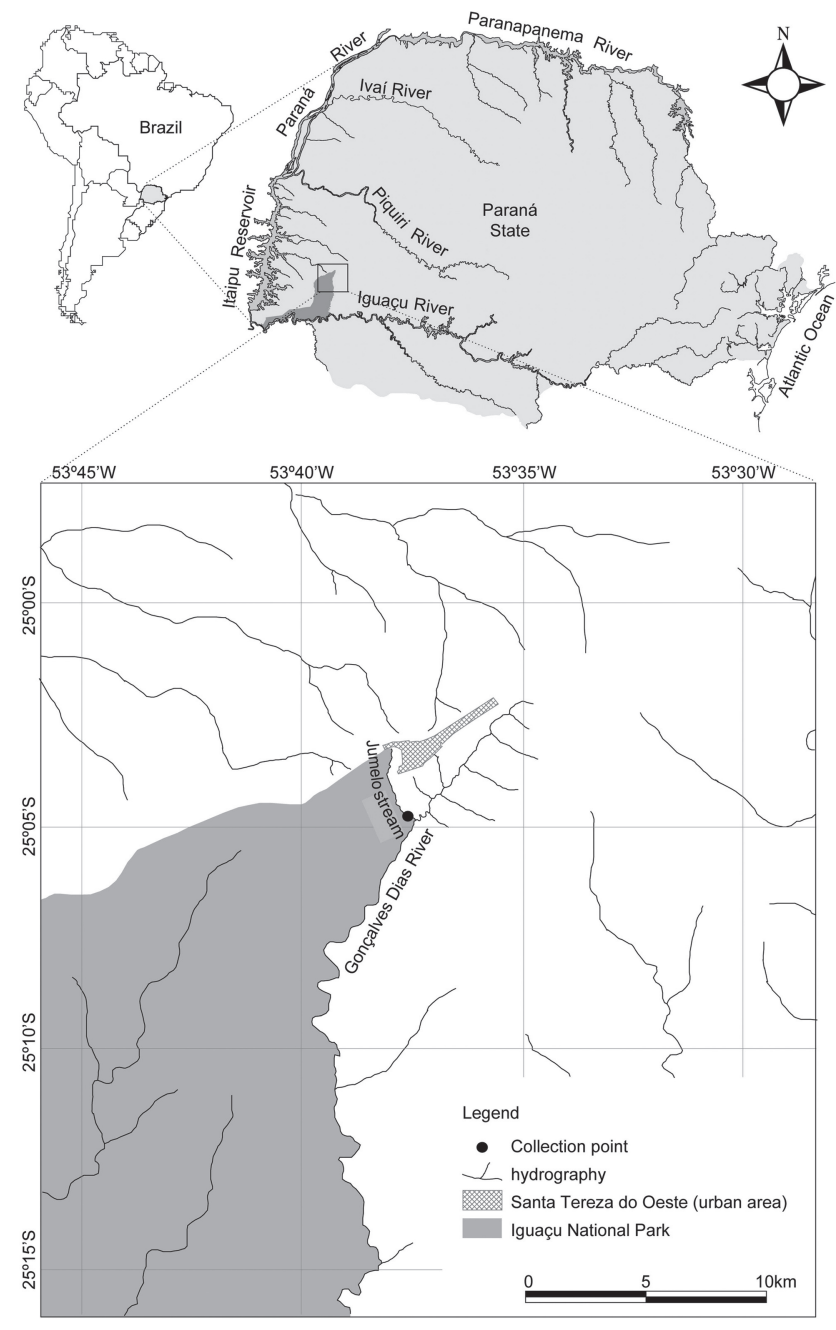

Fig. 1. Study area. Collection point in stream Jumelo, region of the Iguaçu National Park in the Brazilian state of Paraná and Gonçalves Dias River in the Iguaçu River Basin, Santa Tereza do Oeste, Paraná. 
The $50 \mathrm{~m}$ stretch that was sampled for this study is approximately $2.0 \mathrm{~m}$ wide and between 0.20 and $1.0 \mathrm{~m}$ deep, with transparent water. It includes several meanders and has a rocky bottom with gravel, sand and silt, and stretches with wood debris, rapids, deposits of decaying leaves, and woody debris, but no aquatic vegetation. In the upstream portion is a waterfall about $0.5 \mathrm{~m}$ high. Stream banks are stable, with firm soil and shrubs and roots.

Field data collection. Fish were sampled quarterly from September 2011 to June 2012. We used the electrofishing technique, with three passes of $40 \mathrm{~min}$ through reaches of $50 \mathrm{~m}$. The electrofishing equipment was powered by a portable generator (Honda, $2.5 \mathrm{~kW}, 220 \mathrm{~V}, 3-4 \mathrm{~A}$ ) connected to a DC transformer, with two electrified net rings (anode and cathode). Output voltage varied from 400 to $600 \mathrm{~V}$. We installed blocking nets (mesh size $0.5 \mathrm{~mm}$ ) at each end of the reach to prevent the fish from escaping. The collected specimens were immediately killed in a solution of clove oil (Eugenol, 2 drops per liter; American Veterinary Medical Association, 2001), and fixed in 10\% formalin to stop the digestion process. Fish were collected under license from the Instituto Chico Mendes de Conservação da Biodiversidade (ICMBio) (Process No. 30182). Voucher specimens were deposited in the Coleção Ictiológica do Núcleo de Pesquisas em Limnologia, Ictiologia e Aquicultura (NUP), Universidade Estadual de Maringá, Maringá-PR, Brasil (Table 1).

Laboratory procedures. Specimens were identified in the laboratory according to Baumgartner et al. (2012), and then preserved in $70^{\circ} \mathrm{GL}$ ethanol.

Diet. Gastric contents of seven species based on all stomachs with food (fullness equal to or greater than $20 \%$ ) were identified under optical and stereoscopic microscopes to the lowest taxonomic level possible. For species with an undifferentiated stomach (Loricariidae), the contents of the anterior third of the digestive tube were examined. For the analysis of stomach contents, we used only species for which we had a total of five or more samples. Food items were identified using the identification keys of Bicudo \& Bicudo (1970) for algae and Mugnai et al. (2010) for invertebrates, and quantified according to the volumetric method; i.e., the total volume of a food item taken by the fish population is given as a percentage of the total volume of all stomach contents (Hyslop, 1980), using graduated test tubes and a glass counting plate (Hellawell \& Abel, 1971).

Ecomorphology. Thirty individuals of each species were analyzed (including at least five species for which the total number was less than 30), based on 27 morphological characters related to habitat occupation, swimming behavior, and trophic ecology, through linear morphological measurements and areas related to the trunk, fin, head, eye, and mouth (Oliveira et al., 2010; Pagotto et al., 2011). These characters were always taken from the left side of the individuals, and the linear morphometric measurements were obtained with the aid of a digital caliper. In the case Phalloceros harpagos Lucinda, 2008, which has sexual dimorphism, both sexes were measured and included in the analyzes. To calculate the areas of the fins, they were drawn on plastic material and later scanned and inserted in AutoCAD 2007 software. These variables were converted into 15 ecomorphological indexes: compression index, relative length of the caudal peduncle, relative width of the caudal peduncle, relative height of the caudal peduncle, relative area of the dorsal fin, aspect ratio of the caudal fin, relative area of the anal fin, aspect ratio of the anal fin, relative area of the pectoral fin, relative area of the pelvic fin, relative head height, relative head width, relative mouth height, relative mouth width, and relative area of the eye. Additionally the variable orientation of the mouth was coded as 1 - superior position, 2 - terminal position, 3 - oblique ventral position and 4 - ventral position. These indices are important because they minimize the effect of individual size, eliminating the chance that the analysis will be dominated by this variable and focusing primarily on the shape of the body and the structures (Winemiller, 1991).

Data Analysis. For analysis of the diet-composition, the items identified were grouped into broader categories: aquatic invertebrates (Acarina, Decapoda, Cladocera, Conchostraca, Copepoda), aquaticinsects(Ephemeroptera, Odonata nymphs, Plecoptera, Trichoptera, Simuliidae and remains of aquatic insects), terrestrial invertebrates (Oligochaeta and Araneae), terrestrial insects (Hymenoptera, Coleoptera), plants (leaves and seeds of vascular plants), detritus (particulate organic matter in different stages of decomposition and with mineral particles present), algae (Chlorophyta, Bacillariophyceae, Zygnemaphyceae) and Pisces.

Trophic guilds were determined from the matrix of stomach contents by an adaptation of the stepwise procedure of Mérona et al. (2001): more than 50\% detritus/ sediment in the stomachs: detritivores; more than $50 \%$ of aquatic insects in the stomachs: aquatic insectivores; more than $50 \%$ or by adding various invertebrates and fish in the stomachs: carnivores; similar proportions of detritus and aquatic insects: detritivores/insectivores; none of the above statements valid, and adding items from different origins (plant and animal): omnivores.

The Equitability was used to standardize the sampling effort, in which the ratio of abundance was distributed between species and calculated by the index EVAR following Smith \& Wilson (1996):

$$
\text { Evar }=1-2 / \Pi \arctan \left\{\sum_{\mathrm{i}=1}^{s}\left(\operatorname{In}\left(\mathrm{x}_{s}\right)-\sum_{\mathrm{i}=0}^{\mathrm{n}} \operatorname{In}\left(\mathrm{x}_{\mathrm{t}}\right) / \mathrm{S}\right)^{2} / \mathrm{S}\right\}
$$

where $\mathrm{S}=$ volume of the food items in the sample; Xs is the species abundance. 
To evaluate of the level of dietary specialization, the niche breadth was calculated using the standardized Levins index. This index ranges from 0 (when a species consumes a single type of food item) to 1 (when a species consumes all food resources similarly). The index is given by the expression proposed by Hurlbert (1978):

$$
B_{i}=\frac{\left[\left(\frac{1}{\sum_{i=1}^{n} p_{i}^{2}}\right)-1\right]}{(n-1)}
$$

where $\mathrm{B} i=$ standardized index of niche breadth; $\mathrm{Pij}=$ proportion of food category $\mathrm{j}$ in the diet of species $\mathrm{i} ; \mathrm{n}=$ number of food categories ingested by species $i$.

The degree of feeding overlap was analyzed for each species pair, based on the volume of the food items, according to the Pianka index (Pianka 1973), described by the equation:

$$
O_{j k}=\frac{\sum_{i}^{n} P_{i j} \times P_{i k}}{\sqrt{\sum_{i}^{n} P_{i j}^{2} \times \sum_{i}^{n} P_{i k}^{2}}}
$$

where: Ojk $=$ measure of Pianka niche overlap between the species $\mathrm{j}$ and $\mathrm{k}$; Pij = proportion of food item $\mathrm{i}$ in the diet of species $\mathrm{j}$; Pik $=$ proportion of food item $\mathrm{i}$ in the diet of species $\mathrm{k} ; \mathrm{n}=$ total number of food items. This index assumes that prey are equally available to all predators (Reinthal, 1990). The overlap values range from 0 (no overlap) to 1 (complete overlap).

To identify trophic patterns of fish species, we calculated a food-similarity matrix using Manhattan city-block distance. The input matrix for this analysis contained the value for the volume of each food item. A Principal Components Analysis (PCA) was applied on the correlation matrix composed by the 15 ecomorphological indices, aiming to identify patterns in the multivariate ecomorphological space. The axes retained for interpretation were chosen through the Broken-stick criterion (Jackson, 1993; McCune \& Mefford, 2006). The scores of the retained PCA axes were used to calculate an ecomorphological distance matrix (distance between the ecomorphological index).

Mantel's test of matrix comparison was used to test the hypothesis that food similarity may be correlated with morphological similarity (Smouse et al., 1986). The relationship between morphology and trophic structures could be an artifact derived from the phylogenetic distance among the species, in other words, generated from spurious correlations (Winemiller, 1991; Douglas \& Matthews, 1992). Because this, we used a partial Mantel test to evaluate the effect of phylogeny, which tested the partial correlation between two matrices, controlling for the effect of a third. For this purpose, we used the same ecomorphological and trophic matrices and compared to a matrix of taxonomic distance that was constructed according to Douglas \& Matthews (1992). The Mantel test compared the matrix of residuals of the regression of ecomorphological distances on the phylogeny with the matrix of residuals of regression of trophic similarity, having the phylogeny as independent variable.

The null hypothesis was that the ecomorphological patterns of the fish species studied are independent of the use of food resources and of the phylogeny of the species.

To calculate the dietary overlap, we used Ecosim ${ }^{\circledR}$ 7.0 (Gotelli \& Entsminger, 2006). The PCA analysis and the Mantel test were performed in the PAST program (Paleontological Statistics Software) version 2.08 (Hammer et al., 2001).

\section{Results}

Diet composition, guilds and trophic specialization. A total of 1,056 individuals belonging to seven species were captured, and the stomach contents of 419 were analyzed. The dietary analysis showed that the main food items consumed by the fish assemblage were detritus, aquatic and terrestrial insects, and other aquatic invertebrates (Table 1). The species of the genus Astyanax used mainly aquatic and terrestrial insects, followed by plants, and were therefore characterized as omnivores. Ancistrus mullerae Bifi, Pavanelli \& Zawadzki, 2009, fed primarily on detritus, with small proportions of algae (Chlorophyta, Bacillariophyceae, Zygnemaphyceae), and was classified as a detritivore. The diet of Rhamdia branneri Haseman, 1911, was composed predominantly of aquatic invertebrates (Aeglidae), terrestrial plants (seeds), terrestrial invertebrates (Oligochaeta), and fish, and this species was characterized as a carnivore. The species of Trichomycterus proved to be aquatic insectivores, where the most-consumed food items were Simuliidae (larvae) and Ephemeroptera. Phalloceros harpagos, consumed similar proportions of detritus and aquatic insects (Ephemeroptera, Chironomidae and Simuliidae), and was classified as a detritivore/ insectivore. In general, all species showed narrow trophic niches $(\mathrm{Ba}<0.3)$, with the highest specialization observed in A. mullerae (Table 1).

Dietary overlap. In general, the dietary overlap between species was low. Overlap values above 0.6 were observed between trichomycterids and Astyanax, due to shared consumption of Simuliidae larvae, Hymenoptera and plants; and between $A$. mullerae and P. harpagos (88\%), due to consumption of detritus (Table 2).

Ecomorphological diversification and relationships between diet and morphology. The first two axes of the principal components analysis (PCA), retained for interpretation by the Broken-Stick Model, explained $81.42 \%$ of the total variability of the ecomorphological data (Table 3). 
Table 1. Food items consumed by the fish fauna in Jumelo stream, Iguaçu National Park, Paraná, Brazil. Values based on data for percentage volume of the food item. Asterisk indicates values less than $0.01 \%$. Trophic guilds: DET= detritivore; $\mathrm{CAR}=$ carnivore; $\mathrm{ONI}=$ omnivore; $\mathrm{INA}=$ aquatic insectivore; $\mathrm{D} / \mathrm{IN}=$ detritivore/insectivore; $B i$ : Standardized Levins niche width.

\begin{tabular}{|c|c|c|c|c|c|c|c|}
\hline \multirow{2}{*}{$\begin{array}{l}\text { Taxonomic position } \\
\text { Fish fauna }\end{array}$} & \multicolumn{2}{|c|}{ Characiformes } & \multicolumn{4}{|c|}{ Siluriformes } & \multirow{2}{*}{$\begin{array}{l}\text { Cyprinodontiforme } \\
\text { Phalloceros harpago }\end{array}$} \\
\hline & $\begin{array}{c}\text { Axtyanax } \\
\text { bifasciatus }\end{array}$ & $\begin{array}{l}\text { Astyanax } \\
\text { dissimilis }\end{array}$ & Trichomycterus sp. 1 & Trichomycterus sp. 2 & $\begin{array}{c}\text { Ancistrus } \\
\text { mullerae }\end{array}$ & $\begin{array}{l}\text { Rhamdia } \\
\text { branneri }\end{array}$ & \\
\hline Voucher specimens & NUP 16945 & NUP 16940 & NUP 16944 & NUP 12661 & NUP 16942 & NUP 16941 & NUP 16943 \\
\hline Numerical proportion & 2.98 & 0.67 & 30.33 & 8.06 & 46.93 & 3.07 & 7.97 \\
\hline Biomass ratio & 12.4 & 5.13 & 15.34 & 4.46 & 36.92 & 24.06 & 1.69 \\
\hline $\mathrm{N}$ analyzed stomachs & 14 & 5 & 118 & 55 & 148 & 17 & 59 \\
\hline$B i$ & 0.23 & 0.14 & 0.13 & 0.11 & 0.11 & 0.32 & 0.33 \\
\hline Trophic guilds & ONI & ONI & INA & INA & DET & CAR & $\mathrm{D} / \mathrm{IN}$ \\
\hline \multicolumn{8}{|l|}{ Food items } \\
\hline AUTOCHTHONOUS & 28.32 & 40.43 & 99.52 & 99.81 & 0.01 & 60.12 & 49.77 \\
\hline Algae & & & & & 0.01 & & 0.14 \\
\hline Nematoda & 4.37 & & $*$ & & $*$ & & \\
\hline Microcrustaceans & & & & & $*$ & & 1.18 \\
\hline Aeglidae & & 1.7 & 0.81 & & & 33.55 & \\
\hline Fish & & & & & & 7.31 & \\
\hline Ephemeroptera & 0.52 & & 26.47 & 31.84 & & 0.33 & 20.93 \\
\hline Odonata & 0.52 & 21.7 & & & & & \\
\hline Trichoptera & & & 5.24 & 11.18 & & & 1.15 \\
\hline Simulidae & & & 57.29 & 47.68 & & 7.83 & 11.71 \\
\hline Plecoptera & & & & 0.38 & & & \\
\hline Blephariceridae & & & 4.19 & & & & 0.28 \\
\hline Chironomidae & 8.92 & & 1.25 & 3.34 & $*$ & & 13.56 \\
\hline Aquatic insect others & 13.99 & 17.02 & 4.27 & 5.39 & & 11.1 & 0.82 \\
\hline ALLOCHTHONOUS & 71.68 & 59.57 & 0.4 & 0.19 & & 39.88 & 1.04 \\
\hline Plant remains & 33.04 & 10.64 & & & & 30.29 & 0.03 \\
\hline Araneae & 1.92 & 1.91 & & & & & 1.01 \\
\hline Coleoptera & 4.72 & 8.94 & & 0.19 & & 1.11 & \\
\hline Hymenoptera & 27.62 & 35.53 & & & & 1.96 & \\
\hline Terrestrial insect others & 4.37 & 2.55 & 0.4 & & & & \\
\hline Oligochaeta & & & & & & 6.53 & \\
\hline \multicolumn{8}{|l|}{ UNDETERMINED } \\
\hline Detritus & & & 0.08 & & 99.99 & & 49.18 \\
\hline
\end{tabular}

PCA axis 1 (46.1\%) separated $A$. mullerae with positive scores; this species has a dorsoventrally depressed body (low depression index), long caudal peduncle, and welldeveloped swimming fins (except the anal fin). Phalloceros harpagos, Astyanax bifasciatus Garavello \& Sampaio, 2010, and Astyanax dissimilis Garavello \& Sampaio, 2010, showed more negative scores, corresponding to their compressed bodies and peduncles, with a relatively larger eye area and anal fins. Species with more-elongated bodies, oblique ventral mouths and well-developed paired swimming fins had intermediate scores on PCA axis 1. PCA axis $2(35.3 \%)$ tended to segregate those with a longer and higher head and relatively larger areas of the pectoral, caudal and pelvic swimming fins, including $R$. branneri, Trichomycterus $\mathrm{sp} .1$ and Trichomycterus $\mathrm{sp} .2$ (Fig. 2). 
Table 2. Pianka overlap index for trophic niche. calculated for each pair of fish species from Jumelo stream. Iguaçu National Park. Paraná. Brazil. An asterisk indicates high overlap values $(<0.6)$. $\mathrm{Abi}=$ Astyanax bifasciatus; $\mathrm{Adi}=$ Astyanax dissimilis; Tri1 $=$ Trichomycterus sp.1; Tri2= Trichomycterus sp.2; Anc= Ancistrus mullerae; Rha= Rhamdia branneri; $\mathrm{Pha}=$ Phalloceros harpagos .

\begin{tabular}{cccccccc}
\hline & Abi & Adi & Tri1 & Tri2 & Anc & Rha & Pha \\
\hline Abi & - & & & & & & \\
Adi & $0.7276^{*}$ & - & & & & & \\
Tri1 & 0.0207 & 0.0234 & - & & & & \\
Tri2 & 0.0337 & 0.032 & $0.9791^{*}$ & - & & & \\
Anc & 0.0035 & 0 & 0.0003 & 0.001 & - & & \\
Rha & 0.536 & 0.2577 & 0.1481 & 0.1405 & 0 & - & \\
Pha & 0.0412 & 0.0004 & 0.0332 & 0.3701 & $0.8845^{*}$ & 0.0292 & - \\
\hline
\end{tabular}

Table 3. Eigenvectors, eigenvalues and percentage of explicability of the first two axes (PCA 1 and PCA 2) from the principal components analysis (PCA) applied to the correlation matrix of 15 ecomorphological indices and mouth orientation for the fish assemblage in Jumelo stream, Iguaçu National Park, Paraná, Brazil. Values in bold indicate the five respective eigenvectors that more contributed negatively, and the five eigenvectors that more contributed positively to the formation of PCA 1 and PCA 2 .

\begin{tabular}{lcc}
\hline Ecomorphological indices & CP1 & CP2 \\
\hline Compression Index & $\mathbf{- 0 . 3 5 2 7}$ & -0.04459 \\
Relative length of the caudal peduncle & 0.1275 & 0.2225 \\
Relative height of the caudal peduncle & 0.2024 & 0.3175 \\
Relative width of the caudal peduncle & $\mathbf{- 0 . 2 4 4 7}$ & 0.3055 \\
Relative area of the dorsal fin & 0.288 & $\mathbf{- 0 . 2 4 3 5}$ \\
Aspect-ratio of the caudal fin & $\mathbf{- 0 . 1 4 1}$ & $\mathbf{- 0 . 3 0 4 7}$ \\
Relative area of anal fin & $\mathbf{- 0 . 2 7 3 8}$ & $\mathbf{- 0 . 2 7 0 4}$ \\
Aspect-ratio of anal fin & 0.1096 & $\mathbf{0 . 3 5 3 6}$ \\
Relative area of pectoral fin & $\mathbf{0 . 3 1 6}$ & -0.1447 \\
Relative area of pelvic fin & $\mathbf{0 . 3 0 1 4}$ & $\mathbf{- 0 . 2 3 0 4}$ \\
Relative height of the head & $\mathbf{0 . 3 4 7 1}$ & -0.06086 \\
Relative width of the head & 0.07444 & $\mathbf{0 . 3 0 2 3}$ \\
Relative height of the mouth & $\mathbf{0 . 3 1 6 4}$ & $\mathbf{0 . 1 9 4 4}$ \\
Relative width of the mouth & -0.1064 & $\mathbf{0 . 3 8 1 6}$ \\
Relative area of the eye & $\mathbf{- 0 . 2 0 0 4}$ & $\mathbf{- 0 . 1 4 4 7}$ \\
Mouth position & $\mathbf{0 . 3 1 6 8}$ & -0.1748 \\
\hline Eigenvalues & 7.38 & 5.65 \\
\hline Predicted eigenvalues (Broken-stick) & 3.38 & 2.38 \\
Variance (\%) & 46.12 & 35.3 \\
\hline
\end{tabular}

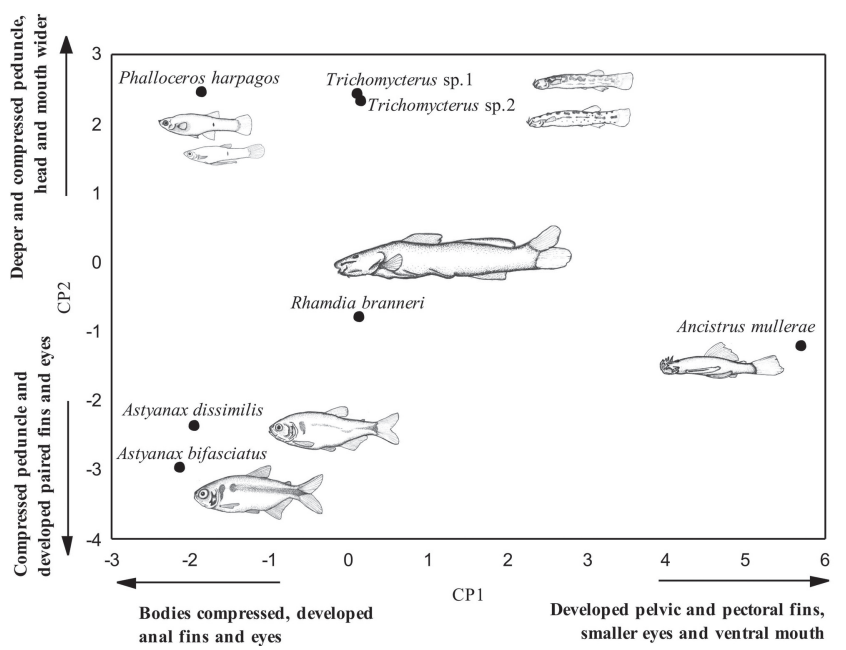

Fig. 2. Ordenation of the fish fauna in Jumelo stream, Iguaçu National Park, Paraná, Brazil, produced by the first two axes of the principal components analysis (PCA 1 and PCA 2) applied to the correlation of 15 ecomorphological indices and the mouth orientations of the fish species.

The Mantel test showed a significant correlation between the matrices of trophic and ecomorphological distances $(\mathrm{r}=0.55, \mathrm{p}=0.01)$. However, the correlation between the morphological and taxonomic matrices was also significant $(r=0.37, p=0.004)$, which could indicate the existence of spurious correlations that are related to the taxonomy of species. Therefore, in order to remove the effect of phylogeny on the relationship between diet and morphology, a partial Mantel test was conducted, which showed a significant correlation between diet and morphology $(r=0.47, p=0.02)$.

\section{Discussion}

Fish assemblage of the stream was structured in five trophic guilds, and the diets of their species reflected the main food resources available for fish in freshwater food webs. Despite the low richness (seven species), the trophic structure is comparable to other tropical fish assemblages, for which higher species richness does not necessarily imply the existence of considerable differences in the composition of the food items (Esteves \& Lobón-Cerviá, 2001; Silva et al., 2012).

The variety of autochthonous and allochthonous resources in the diets of the fish species reflects the functional-trophic integrity of this ecosystem. This is verified by the presence of (i) a considerable amount of terrestrial insects (Hymenoptera and Coleoptera), seeds, and plants, which attests to the contribution of the riparian vegetation to the input of organic matter to the system (Uieda \& Pinto, 2011; Casatti, 2010; Moraes et al., 2013); (ii) the presence of organisms such as Ephemeroptera, Trichoptera, Plecoptera and Decapoda (Aeglidae) that are considered to be bioindicators of environmental quality 
and the structural complexity of the river bed (Bispo et al., 2006; Bagatini et al., 2012; Silva et al., 2012). In these context, the results about fish's diet, indicate that the Jumelo stream may used as a possible reference environment (sensu Ferreira \& Casatti, 2006) for comparisons of trophic ecology between fish communities in impacted versus nonimpacted environments. On the other hand, this status of conservation, nowadays little reported to streams, reflects the regional importance of the INP for the functionality of the local aquatic communities, especially to an endemic fish fauna, with increasing threat of extinction.

In contrast to what is expected for communities with low species richness, where the niche breadth of species tends to be higher (Hutchinson, 1957; Uieda \& Motta, 2007), for the stream fish assemblage examined here, the dietary niche breadth was markedly low. Even omnivorous species (Astyanax spp.) had low values for diet breadth (below 0.2), which shows that although the species used resources from different trophic levels, their diets tended to be restricted to a small number of abundant items. For streams with higher species richness, the diet breadth has also been found to be low (Wolff et al., 2013; Winemiller et al., 2008). These patterns and the results found here suggest that dietary specialization may not necessarily be linked only to interspecific competition or to the availability of resources (Esteves \& Lobón-Cerviá, 2001; Mazzoni et al., 2012; Vitule et al., 2013).

Other factors may explain the results found here. One, reported by Schoener (1974) and other investigators (MacArthur \& Pianka, 1966; MacArthur \& Levins, 1964; Ross, 1986) is spatial segregation, which could more consistently contribute to the differentiation of niches in narrower tracks. Therefore, low species richness does not necessarily lead to wider trophic breadth, but on the other hand, specialized trophic niches would be a consequence of morphological limitations associated with feeding resources in habitat mosaics (Pringle et al., 1988). This hypothesis gains support because the dietary overlap of this assemblage was high only for those congeneric species with similar morphologies. Moreover, morphology was a significant factor in the use of food, supporting the idea of specialization mediated by morphological constraints.

In ecomorphological studies, fish assemblages with low species richness, i.e., depleted (sensu Hutchinson, 1957), may occupy a total volume of the niche (represented by the multivariate ecomorphological space) that is relatively smaller compared to more-diverse taxocenes (Watson \& Balon, 1984; Winemiller, 1992; Montana et al., 2014). This raises the question of whether fish assemblages with low richness would really show the main ecomorphotypes associated with the use of food resources (Gatz, 1979; Winemiller, 1991; Breda et al., 2005; Oliveira et al., 2010). However, the fish assemblage of Jumelo stream included the main ecomorphotypes (benthic, nektonic and nektobenthic) that are found in other aquatic ecosystems with higher species richness (Casatti \& Castro, 2006;
Cochran-Biederman \& Winemiller, 2010; Mazzoni et al., 2010; Oliveira et al., 2010).

Distribution of species in ecomorphological space indicated the attributes that strongly influenced the feeding habitats of the species. The armored catfish A. mullerae, with a depressed body (benthic ecomorphotype), has a long caudal peduncle and well-developed paired fins, which provide stability in riffles (Bernoulli effect) (Webb et al., 1996; Breda et al., 2005; Oliveira et al., 2010; Pagotto et al., 2011). Together with these adaptations, its mouth with sucking lips favors the uptake of debris and algae from the streambed.

Species with compressed bodies and peduncules, and relatively larger eye area and anal fins (nektonic ecomorphotype) were segregated. Their feeding habits are driven by the visual capacity, which enhances the capture of allochthonous items in the water column (Mazzoni et al., 2010). This group consisted of two species of Astyanax (Characiformes) and the poeciliid P. harpagos (Cyprinodontiformes). According to Breda et al. (2005), fish with these morphological attributes can maneuver more easily and exploit habitats with slower currents. In the case of $P$. harpagos, the dorsally located mouth located probably allows it to ingest debris and aquatic insects from along the banks more than directly on the riverbed. According to Mazzoni et al. (2011), individuals of $P$. harpagos showed non-size-related and non-random patterns of microhabitat use, positively selecting fine-grained sediments, pools (slow water) and shallow locations with or without plant cover, which corroborated the present results.

Species with elongated bodies, ventrally oblique mouths and well-developed paired and caudal fins occupied the intermediate region of the ecomorphological space, and composed the nectobenthos. These species, composited by medium size elongated bodies, like many neotropical catfishes, usually have a generalist feeding profile, because they can be both botton pickers and drift-feeders (Sazima, 1986; Casatti \& Castro, 2006), what diversifies their food intake. The second highest value of niche breadth $(B i=$ 0.32 ), presented by $R$. branneri corroborate this, but the smaller size of Trichomycterus spp. probably limited them to a norrowed trophic niche. The elongated body of $R$. branneri seems to favor both the capture of decapods (Aeglidae) among large rocks, and taking allochthonous plants and fish in the water column, which indicates that it exploits various environmental compartments, a common feeding behavior previously reported for members of this genus (Silva et al., 2012; Vitule et al., 2013). On the other hand, Trichomycterus sp.1 and Trichomycterus sp.2, which also have elongated bodies and ventrally oblique mouths, although smaller body sizes, exploited shallow backwaters and the spaces among cobbles and pebbles, which concords with their high consumption of aquatic insect larvae.

Body shape was significantly correlated with diet, implying that morphologically similar species tend to use similar food resources, independently of their phylogenetic 
(taxonomic) relationships. This indicates that this fish assemblage is structured ecomorphologically, i.e., the diet is significantly predictable from the morphological diversity of the species. So, the nature of food resources probably imposed a evolutionary selection pressure on the more-adaptive ecomophological characteristics of this assemblage. The species morphological potentialities allow them to succesfully capture specific food items, allowing them to coexist in the different microhabitats of this system.

As far as we are aware, our study is the first to examine relationships between the diet and the ecomorphological patterns of stream fishes in a relatively species-poor assemblage. However, further studies on other Neotropical streams with different fish assemblages may help to address several questions that still remain unresolved, as for example, whether or not the correlations among ecomorphotypes and feeding patterns elucidated in our study occur in other depauperate fish assemblages. Alternatively, whether increased fish species richness may cause inter-specific competition and subsequent shifts in ecomorphological and trophic patterns of these more-diverse fish assemblages.

In summary, the main trophic and ecomorphological patterns observed here suggest that low richness, contrary to our initial hypothesis, does not result in broadening the trophic niches of the species or in the absence of some main ecomorphological groups (e g., benthonic, nektonic and nektobenthic). In this situation, an alternative mechanism for the low values of diet breadth would proceed from morphological constraints that limit the species to the use of specific food resources. This assumption has some support, since the feeding overlap was high only between congeneric species (e.g., similar morphologies), and the correlation between diet and morphology was significant. In the context of an endemic fish assemblage with low richness, knowning the trophic and morphological patterns is of fundamental importance since the loss of a single species represents not only the loss of a biological entity, but also the possible loss of an entire trophic guild or ecomorphological group, as well as of the roles that they play in the ecosystem.

\section{Acknowledgments}

We thank UNIOESTE for the support needed to perform the analyses, $\mathrm{CNPq}$ for granting a scientific-initiation scholarship, and members of the fish ecology laboratory for helping in field collections and processing of part of the material. The English language was revised by Janet W. Reid (JWR Associates).

\section{References}

Abilhoa, V., L. F. Duboc \& D. P. A. Filho. 2008. A comunidade de peixes de um riacho de floresta com Araucária, alto rio Iguaçu, sul do Brasil. Zoologia, 5: 238-246.
American Veterinary Association Medical Association. 2001. Report of the AVMA panel on euthanasia. Javma, 218: 669696.

Bagatini, Y. M., R. L. Delariva \& J. Higuti. 2012. Benthic macroinvertebrates community structure in a stream of the Northwest region of Paraná State, Brazil. Biota Neotropica, 12: 307-317.

Baumgartner, G., C. S. Pavanelli, D. Baumgartner, A. G. Bifi, T. Debona \& V. A. Frana. 2012. Peixes do baixo rio Iguaçu. Maringá, Eduem.

Bicudo, C. E. M. \& R. M. T. Bicudo. 1970. Algas de águas continentais brasileiras chave ilustrada para identificação de gêneros. São Paulo, Fundação Brasileira para o Desenvolvimento do Ensino de Ciências.

Bispo, P. C., L. G. Oliveira, L. M. Bini \& K. G. Sousa. 2006. Ephemeroptera, Plecoptera and Trichoptera assemblages from riffles in mountain streams of Central Brazil: environmental factors influencing the distribution and abundance of immatures. Brazilian Journal of Biology, 66: 611-622.

Breda, L., E. F. Oliveira \& E. Goulart. 2005. Ecomorfologia de locomoção de peixes com enfoque para espécies neotropicais. Acta Scientiarum Biological Sciences, 27: 371-381.

Carvalho, E. M. \& V. S. Uieda. 2010. Input of litter in deforested and forested areas of a tropical headstream. Brazilian Journal of Biology, 70: 283-288.

Casatti, L. 2010. Alterações no código florestal brasileiro: impactos potenciais sobre a ictiofauna. Biota Neotropica, 10: 31-34.

Casatti, L. \& R. M. C. Castro. 2006. Testing the ecomorphological hypothesis in a headwater riffles fish assemblage of the river São Francisco, southeastern Brazil. Neotropical Ichthyology, 4: $203-214$

Cochran-Biederman, J. L. \& K. O. Winemiller. 2010. Relationships among habitat, ecomorphology and diets of cichlids in the Bladen River, Belize. Environmental Biology of Fishes, 88: 143-152.

Cruz, B. B., L. E. Miranda \& M. Cetra. 2013. Links between riparian land cover, in stream environment and fish assemblages in headwater streams of south eastern Brazil. Ecology of Freshwater Fish, 22: 607-616.

Daga, V. S., E. A. Gubiani, A. M. Cunico \& G. Baumgartner. 2012. Effects of abiotic variables on the distribution of fish assemblages in streams with different anthropogenic activities in southern Brazil. Neotropical Ichthyology, 10: 643-652.

Delariva, R. L. \& J. C. Silva. 2013. Fish fauna of headwater streams of Perobas Biological Reserve, a conservation unit in the Atlantic Forest of the Northwestern Paraná State, Brazil. Check List 9(3): 549-554.

Douglas, M. E. \& W. J. Matthews. 1992. Does morphology predict ecology? Hypothesis testing within a freshwater stream fish assemblage. Oikos, 65: 213-224.

Esteves, K. E. \& J. Lobón-Cerviá. 2001. Composition and trophic structure of a clear water Atlantic rainforest stream in southeastern Brazil. Environmental Biology of Fishes, 62: 429-440.

Ferreira, C. P. \& L. Casatti. 2006. Integridade biótica de um Córrego na bacia Alto Rio Paraná avaliada por meio da comunidade de peixes. Biota Neotropica, 6: 1-25.

Garavello, J. C., C. S. Pavanelli \& H. I. Suzuki. 1997. Caracterização da ictiofauna do rio Iguaçu. Pp. 61-84. In: Agostinho, A. A. \& L. C. Gomes (Eds.). Reservatório de Segredo: bases ecológicas para o manejo. Maringá, Eduem. 
Gatz Jr., A. J. 1979. Ecological morphology of freshwater stream fishes. Tulane Studies in Zoology and Botany, 21: 91-124.

Gotelli, N. J. \& G. L. Entsminger. 2006. EcoSim: null models software for ecology. Version 7. Acquired Intelligence and Kesey- Bear. Jericho, Vermont, USA. Available online from: http:// garyentsminger.com/ecosim.htmi (Accessed: 30/ October/2013).

Hammer, D. A., T. Harper \& P. D. Ryan. 2001. PAST: Paleontological Statistics Software package for education and data analysis. Paleontologia Electronica, 4: 1-9.

Hellawell, J. M. \& R. Abel. 1971. A rapid volumetric method for the analysis of the food of fishes. Journal of Fish Biology, 3: 29-37.

Herder, F. \& J. Freyhof. 2006. Resource partitioning in a tropical stream fish assemblage. Journal of Fish Biology, 69: 571589.

Hurlbert, S. H. 1978. The measurement of niche overlap and some relatives. Ecology, 59: 67-77.

Hutchinson, G. E. 1957. Concluding remarks. Cold Springs Harbor Symposia on Quantitative Biology, 22: 415-427.

Hyslop, E. J. 1980. Stomach content analysis: a review of methods and their application. Journal of Fish Biology, 17: 411-429.

Jackson, D. A. 1993. Stopping rules in principal components analysis: a comparison of heuristical and statistical approaches. Ecology, 74: 2204-2214.

Langeani, F., R. M. C. Castro, O. T. Oyakawa, O. A. Shibatta, C. S. Pavanelli \& L. Casatti. 2007. Diversidade da ictiofauna do Alto Rio Paraná: composição atual e perspectivas futuras. Biota Neotropica, 7: 1-17.

Leduc, A. O. H. C., E. M. Silva \& J. S. Rosenfeld. 2015. Effects of species vs. functional diversity: Understanding the roles of complementarity and competition on ecosystem function in a tropical stream fish assemblage. Ecological Indicators, 48: 627-635.

MacArthur, R. H. \& R. Levins. 1964. Competition, habitat selection and character displacement in a patchy environment. Proceedings of the National Academy of Sciences, 51: 12071210.

MacArthur, R. H. \& E. R. Pianka. 1966. On optimal use of a patchy environment. American Naturalist, 100: 603-604.

Mazzoni, R., P. S. Marques, C.F. Rezende \& R. Iglesias-Rios. 2012. Niche enlargement as a consequence of co-existence: a case study. Brazilian Journal of Biology, 72: 1-8.

Mazzoni, R., M. Moraes, C. F. Rezende \& J. C. Miranda. 2010. Alimentação e padrões ecomorfológicos das espécies de peixes de riacho do alto rio Tocantins, Goiás, Brasil. Iheringia, 100: 162-168.

Mazzoni, R., V. C. Novaes \& R. Iglesias-Rios. 2011. Microhabitat use by Phalloceros harpagos Lucinda (Cyprinodontiformes: Poeciliidae) from a coastal stream from Soutjeast Brazil. Neotropical Ichthyology, 9: 665-672.

McCune, B. \& M. J. Mefford. 2006. PC-ORD, version 5.0, Multivariate analysis of ecological data. Gleneden Beach, MjM Solfware Desing.

Mérona, D., G. M. Santos \& R. G. Almeida. 2001. Short term effects of Tucuruí Dam (Amazônia, Brazil) on the trophic organization of fish communities. Environmental Biology of Fishes, 60: 375-392.

Mise, F. T., R. Fugi, J. P. A. Pagotto \& E. Goulart. 2013. The coexistence of endemic species of Astyanax (Teleotei: Characidae) is propitiated by ecomorphological and trophic variations. Biota Neotropica, 13: 21-28.
Montana, C. G., K. O. Winemiller, \& A. Sutton. 2014. Intercontinental comparison of fish ecomorphology: null model tests of community assembly at the patch scale in rivers. Ecological Monographs, 84: 91-107.

Moraes, M., C. F. Rezende \& R. Mazzoni. 2013. Feeding ecology of stream-dwelling Characidae(Osteichthyes: Characiformes) from the upper Tocantins River, Brazil. Zoologia, 30: 645651.

Mugnai, R., J. L. Nessimian \& D. F. Baptista. 2010. Manual de identificação de macroinvertebrados aquáticos do estado do Rio de Janeiro. Rio de Janeiro, Technical Boocks.

Nogueira, C., P. A. Buckup, N. A. Menezes, O. T. Oyakawa, T. P. Kasecker, M. B Ramos Neto \& J. M. C. Silva. 2010. Restricted-range fishes and the conservation of Brazilian freshwaters. PLoS One, 5: 1-10.

Oliveira, E. F., E. Goulart, L. Breda, C. V. Minte-Vera, L. Ricardo, D. S. Paiva \& M. R. Vismara. 2010. Ecomorphological patterns of the fish assemblage in a tropical floodplain: effects of trophic, spatial and phylogenetic structures. Neotropical Ichthyology, 8: 569-586.

Pagotto, J. P. A., E. Goulart, E. F. Oliveira \& C. B. Yamamura. 2011. Trophic ecomorphology of Siluriformes (Pisces, Osteichthyes) from a tropical stream. Brazilian Journal of Biology, 71: 469-479.

Pianka, E. R. 1973. The structure of lizard communities. Annual Review of Ecology and Systematics, 4: 53-74.

Pouilly, M., F. Lino, J. G. Bretenoux \& C. Rosales. 2003. Dietary-morphological relationship in a fish assemblage of the Bolivian Amazoniam floofplain. Journal of Fish Biology, 62: 1137-1158.

Pringle, C. M., R. J. Naiman, G. Bretschko, J. R. Karr, M. W. Oswood, J. N. Webster, R. L. Welcomme \& M. J. Winterbourn. 1988. Patch dynamics in lotic systems: the stream as a mosaic. Journal of the North American Benthological Society, 7: 503524.

Reinthal, P. N. 1990. The feeding habits of a group of herbivorous rock-dwelling cichlid fishes (Cichlidae: Perciformes) from Lake Malawi, Africa. Environmental Biology of Fishes, 27: 215-233.

Ross, S. T. 1986. Resource partitioning in fish assemblages: a review of field studies. Copeia, 1986: 352-388.

Sazima, I. 1986. Similarities in feeding behaviour between some marine and freshwater fishes in two tropical communities. Journal of Fish Biology, 29: 53-65.

Schoener, T. W. 1974. Resource partitioning in ecological communities. Science, 185: 27-39.

Silva, J. C., R. L. Delariva \& K. O. Bonato. 2012. Food-resource partitioning among fish species from a first-order stream in northwestern Paraná, Brazil. Neotropical Ichthyology, 10: 389-399.

Smith, B. \& J. B. Wilson. 1996. A consumer's guide to evenness indices. Oikos, 76: 70-82.

Smouse, P. E., J. C. Long \& R. R. Sokal. 1986. Multiple regression and correlation extensions of the Mantel Test of matrix correspondence. Systematic Zoology, 35: 627-632.

Tabarelli, M., L. P. Pinto, J. M. C. Silva, M. M. Hirota \& L. C. Bedê. 2005. Desafios e oportunidades para a conservação da biodiversidade na Mata Atlântica brasileira. Megadiversidade, 1: 132-138.

Uieda, V. S. \& R. L Motta. 2007. Trophic organization and food web structure of southeastern Brazilian streams: a review. Acta Limnologica Brasiliensia, 19: 15-30. 
Uieda, V. S. \& T. L. F. Pinto. 2011. Feeding selectivity of ichthyofauna in a tropical stream: space-time variations in trophic plasticity. Community Ecology, 12: 31-39.

Vitule, J. R. S., F. F. Gazola-Silva, H. Bornatowski \& V. Abilhoa. 2013. Feeding ecology of fishes in a coastal Atlantic Rain Forest River. Environmental Biology of Fishes, 96: 10291044.Watson, D. J. \& E. K. Balon. 1984. Ecomorphological analysis of fish taxocenes in rainforest streams of northern Borneo. Journal of Fish Biology, 25: 371-384.

Webb, P. W., G. D. Laliberte \& A. J. Schrank. 1996. Does body and fin form affect the maneuverability of fish traversing vertical and horizontal slits? Environmental Biology of Fishes, 46: 7-14.

Winemiller, K. O. 1991. Ecomorphological diversification in lowland freshwater fish assemblages from five biotic regions. Ecological Monographs, 61: 343-365.

Winemiller, K. O. 1992. Ecological Divergence and Convergence in Freshwater Fishes. National Geographic Research \& Exploration, 8: 308-327.
Winemiller, K. O., A. A. Agostinho \& E. P. Caramaschi. 2008 Fish ecology in tropical streams. Pp. 107-146. In: Dudgeon, D. (Ed.). Tropical stream ecology. San Diego, Elsevier/ Academic Press.

Wolff, L. L., N. Carniatto \& N. S. Hahn. 2013. Longitudinal use of feeding resources and distribution of fish trophic guilds in a coastal Atlantic stream, southern Brazil. Neotropical Ichthyology, 11: 375-386.

Zawadzki, C. H., E. Renesto \& L. M. Bini. 1999. Genetic and morphometric analysis of three species of the genus Hypostomus Lacépède, 1803 (Osteichthyes: Locariidae) from the Rio Iguaçu basin (Brasil). Revue Suisse de Zoologia, 106: 91-105.

Submitted August 28, 2014 Accepted December 11, 2014 by Norma Segatti Hahn Published March 31, 2015 